\title{
DOKUMENTARNI FILM U OBRAZOVNOM PROCESU: REPOZICIONIRANJE CILJEVA
}

\section{Sažetak}

Cilj ovog rada je da istraži efekte do sada objavljenih nastavnih priručnika programa Slobodna zona Junior (Fond B92) kojima se repozicionira dokumentarni film u obrazovnom procesu Srbije, najpre u nastavi građanskog vaspitanja u osnovnim i srednjim školama, a zatim i na Univerzitetu kroz master program Centra za obrazovanje nastavnika na Filozofskom fakultetu. Glavni fokus biće na publikaciji Film u nastavi: priručnik za studente - buduće nastavnike (2017), koji kao osnovu i preporučenu metodiku nastave navodi stav da se analizom najvećeg broja dokumentarnih filmova može dublje istražiti njihov kulturni, socijalni, istorijski i politički značaj u društvu u kojem su nastali. Stoga osposobljavanje profesionalaca u obrazovanju za korišćenje dokumentarnog filma kao nastavnog sredstva ima potencijal da inspiriše dijalog i otvori teme za debatu. Srbija

Ključne reči: dokumentarni film, debata, metodika nastave, obrazovni sistem,

Evropske studije Za evropsku filmsku obrazovnu politiku (For a European Film Education Policy, 2014) i Medijska (ekranska) pismenost, filmsko obrazovanje u Evropi (Screening Literacy, Film Education in Europe, 2013) ukazuju na važnost medijskog, a posebno filmskog, obrazovanja i pismenosti kod dece i omladine. Naročito značajno u ovim studijama je to što one prepoznaju i na prvom mestu ističu školske kurikulume kroz koje će se deca upoznavati sa sadržajima i ekranima koji ih okružuju. Kao dobri modeli predstavljaju se francuski programi Škola u bioskopu (Ecole et 
cinéma, 1994), Škola filma (Collège au cinéma, 1989) i Filmski početnici i učenici (Lycéens et apprentis au cinéma, 1998). Srbija se zahvaljujući edukativnim programima Film kultura ${ }^{2}$ i Slobodna zona Junior približava evropskim trendovima, ali samo u vanškolskim aktivnostima. Potreba za funkcionalnom povezanošću ekranske kulture, medijske pismenosti, audio-vizuelnog obrazovanja i školskih kurikuluma danas je sve izraženija, jer su deca i omladina potpuno okruženi medijima i ekranima: kuda god da se kreću, oni su svuda oko njih, a da pritom za slike i sadržaji koje im se na tim ekranima nude ne znaju na koji način nastaju i šta znače (Poter 2011). Uspostavljanje novih obrazovnih sadržaja u ovom smeru omogući će im da pokretne slike na ekranima svih vrsta razumeju ne samo kao sredstva komunikacije i razmene mišljenja, već i mogućeg kreativnog izražavanja u oblasti audio-vizuelne kulture i umetnosti (Gone 1998).

Program Slobodna zona Junior nastao je u okviru Fonda B92 i filmskog festivala angažovanog filma Slobodna zona, a podeljen je na dva segmenta: Film kao dodatno nastavno sredstvo i Kamp angažovanog dokumentarnog filma za srednjoškolce ${ }^{3}$. U okviru predmeta Građansko vaspitanje, Film kao dodatno nastavno sredstvo nastoji da modernizuje nastavu i učini je interaktivnom, a pokrenut je kao odgovor na potrebu za modernizacijom nastave pružanjem podrške institucionalnom dizanju svesti među mladima o

Film kulturu je 2013. godine osnovalo šest mladih filmskih umetnika iz različitih sfera kinematografije (režije, produkcije, dramaturgije, montaže, kamere) u želji da deci i omladini prenesu deo svog iskustva i znanja iz oblasti audio-vizuelne kulture, a pre svega kinematografije. Niz radionica ove organizacije se odvija kroz „teorijska predavanja, projekcije audio-vizuelnih sadržaja (film, TV, video-art), sa posebnim akcentom na stimulaciju kritičkog razmišljanja, praktične vežbe prilagođene uzrastu i profilu učesnika“. Edukativni program organizacije Film kultura podeljen je prema uzrastu na decu u predškolskim ustanovama (5-6 godina), učenike osnovnih škola (7-15 godina) i učenike srednjih škola (15-19 godina).

3 Kamp angažovanog dokumentarnog filma Slobodna zona Junior koncipiran je kao radionica za srednjoškolce. Cilj radionice jeste da grupi izabranih srednjoškolaca pruži uvid u uzroke, posledice i domete društvenog aktivizma, u različite aspekte kreiranja društveno angažovanog filma, da ih ohrabri na interkulturalni dijalog, podstakne i podrži u razvijanju sopstvenih ideja. Kamp se sastoji iz dva dela. Tokom prvog (dvonedeljnog) dela kampa polaznici stiču veštine u pisanju scenarija, dramaturgiji, strukturi filma, montaži, kameri, ali i znanja o istorijatu i karakteristikama dokumentarnog filma, sa posebnim osvrtom na primere angažovanog filma. Polaznici imaju priliku i da se susretnu sa rediteljima i producentima angažovanih dokumentarnih filmova iz regiona. U drugom (sedmodnevnom) delu kampa polaznici rade na oživljavanju svojih ideja filmskih scenarija. Uz predavanja o pičingu i vežbe prezentovanja svojih ideja filmskim profesionalcima, oni se pripremaju za završni deo kampa, a to je realizacija sopstvenih kratkih dokumentarnih filmova. 
pitanjima ljudskih prava. Cilj je da se kroz audio-vizuelne umetnosti i vannastavne aktivnosti osnovcima i srednjoškolcima pruži prilika da na kreativan način izraze svoje stavove. Namenjen je nastavnicima, a obuhvata izdavanje DVD kompilacije edukativnih angažovanih filmova, publikovanje priručnika sa predloženim radionicama koje prate filmove, kao i organizovanje seminara za korišćenje filma u nastavi. U ovom programu od 2006. godine do danas učestvovala su 524 nastavnika iz 268 srednjih škola i 86 gradova širom Srbije. Tokom školske 2011/2012. Slobodna zona Junior izdala je prvi priručnik za osnovne škole uz prateću kompilaciju filmova i organizovala 27 radionica za nastavnike u kojima je učestvovalo 667 prosvetnih radnika iz 426 osnovnih škola iz 181 mesta širom Srbije.

Slobodna zona Junior objavila je do sada tri priručnika: Slobodna zona u srednjim školama: filmovi u nastavi građanskog vaspitanja (2008), Slobodna zona u srednjim školama: filmovi u nastavi građanskog vaspitanja (2009) i Slobodna zona: priručnik za osnovne škole: filmovi u nastavi građanskog vaspitanja (2011). Nova publikacija Film u nastavi: priručnik za studente - buduće nastavnike, koju prati DVD priručnik sa 13 dokumentarnih filmova, predstavlja dopunjenu i izmenjenu verziju izdanja Dokumentarni film u nastavi (2015) češkog modela Jedan svet u školama. Uz podršku američke fondacije Nacionalna zadužbina za demokratiju (NED National Endowment for Democracy), izdanje je realizovano 2017. godine u partnerstvu organizacije Čovek u nevolji (Člověk v tísni), Slobodne zone Junior (Fond B92) i Centra za obrazovanje nastavnika (Filozofski fakultet Univerziteta u Beogradu). U okviru njihovog master programa namenjenog obrazovanju nastavnika i programa celoživotnog učenja Obrazovanje nastavnika predmetne nastave, školske 2016/2017. godine realizovan je predmet Film u nastavi. Njegov razvoj podrazumevao je prilagođavanje i proširenje teorijskog okvir za bolje razumevanje značenja filma, rekonceptualizaciju primene dokumentarnog filma u nastavi, prevod i dopune češkog priručnika, itd. Kao važno se navodi pojašnjenje i rasvetljavanje značaja „medija u savremenom društvu, kulturi i obrazovanju; savremenih shvatanja obrazovanja i učenja, saznanja o interaktivnoj nastavi kao kontekstu za korišćenje filma u nastavi i o odnosu umetnosti, angažovanog obrazovanja i filma, kao i detaljnije razrade bavljenja kontroverznim temama“ (Popadić et.al 2017, 8). 
Obrazovanje, kao emancipatorska praksa, danas ima naglašenu ulogu u razvoju konvergencije filma i novih medija, kao i njihove sinergije sa drugim umetnostima i naučnim disciplinama. Očuvanjem kulture posete bioskopskih predstava i gledanja filmova, održava se specifičan vid recepcije koji podrazumeva "normativni set naučenih ponašanja i praksi“ (Lotz 2007: 29), kupovinu ulaznice, određeno vreme početka projekcije, reklame i trejlere pre početka filma, mrak i tišinu tokom filma itd. Takođe, podstiče se stvaralački potencijal kod mladih za ovu umetnost (Makluan 2012). Stoga je cilj izbornog predmeta Film u nastavi, koji vodi tim predavača prof. dr Dragan Popadić, prof. dr Vera Rajović, doc. dr Lidija Radulović i doc. dr Milan Stančić, usmeren na to da se profesionalci u obrazovnom sistemu osposobe za korišćenje filma kao nastavnog sredstva. Pretpostavljeni ishod predmeta je da student tj. budući nastavnik ne koristi film kao tradicionalno već savremeno nastavno sredstvo u: izboru filma koji inspiriše i utiče na celovit razvoj učenika; otvaranju i započinjanju tema, jer dokumentarni film nema samo jedno čitanje, već različite nivoe interpretacije; uticaju na potrebe učenika i društveni kontekst, u smislu osetljivosti za društvene probleme, potrebe različitih društvenih grupa, kontraverzne teme koje izazivaju snažne emocije; izboru metoda i tehnika koje strukturiraju aktivnosti učenika i organizuje diskusiju na času, itd.

\section{AKTUELNOST DOKUMENTARNOG FILMA}

U različitim vrstama dokumentarnog sadržaja, od dugometražnih dokumentarnih filmova do filmskih i televizijskih reportaža, u kojima se predstavljaju i tumače određeni istorijski periodi i događaji, najvažnije je uspostaviti korelaciju između tri strane: 1 ) istorijskih, kulturnih, političkih i društvenih procesa; 2) njihove medijske reprezentacije; i 3) publike i njene recepcije, čitanja i interpretacije ovih procesa kroz dokumentarne tekstove. Ova tri aspekta uslovljavaju da savremeni mediji utiču na način na koji recipijenti „gledaju, veruju i razumeju“ (Ibrahim 2009, 95) medijske tekstove, a zbog masovnosti njihovog prikazivanja zauzimaju centralno mesto u kreiranju sećanja i prostora kolektivne identifikacije.

Gledaoci se u toku gledanja dokumentarnih filmova najčešće oslanjaju na vernost, autentičnost, verodostojnost i objektivnost prikazivanja 
(Kerner 2011). Zbog toga Vivijan Šobček (Vivian Sobchack) stavlja akcenat na gledaočevu percepciju, razumevanje i interpretaciju dokumentarnih sadržaja i naglašava da se njihova žanrovska oznaka „najpre odnosi na objektivnost kao opšteprihvaćenu odliku ovog žanra, a termin - mnogo radikalnije - označava i subjektivni odnos spram objektivnog filmskog ili televizijskog teksta" (Sobchack 1999, 241). Svi ovi aspekti filmskih ili televizijskih dokumentarnih programa snažno utiču na ono što publika spoznaje i za šta veruje da je istinito o određenom istorijskom periodu ili događaju dok gleda njihovo audio-vizuelno predstavljanje u dokumentarnom žanru.

Za razliku od istorijskih knjiga i dokumenata, dokumentarni film ima moć da veoma živo odslikava prošlost, zbog čega ovaj filmski žanr ima važnu društvenu i istorijsku odgovornost da sačuva pamćenje iz prošlosti kako bi obezbedio efikasne načine saznanja o njoj za sadašnje i buduće generacije. $U$ dokumentarnim filmovima arhivski (audio-vizuelni) materijali, fotografije, naratorski glas (voice-over narration), izjave eksperata i svedoka, itd. mogu pomoći boljem razumevanju prošlosti i istorije, ali mogu i uticati na njihova nova, alternativna, ali i pogrešna čitanja. Autori dokumentarnih filmova nastoje da što jasnije predstave autentične, proverene, faktografske, relevantne i objektivne činjenice o svetu, pretendujući na (vanvremensku) aktuelnost, te se njihovom analizom mogu istražiti i razumeti različiti aspekti u društvu u kojem su nastali (Milovanović 2016a).

$U$ dokumentarnom žanru „ne posmatra se stvarnost samo kroz činjenice koje treba predstaviti, već kao društvena i istorijska stvarnost koja se jedino može razumeti u kontekstu društvenih sila koje je proizvode" (Britton 1992, 29). lako su najvažnije konvencije i kodovi ovog žanra objektivnost i verodostojnost, autori dokumentarnih tekstova, od filmskih do televizijskih, „svoje dokaze predstavljaju kroz pažljivo organizovanu strukturu koja nastaje usled određene autorske tačke gledanja“ (ibid). Kroz dokumentarni film umetnici imaju odgovornost da postavljaju pitanja, pozivaju na debatu, istražuju, preispituju, analiziraju, dopunjavaju i revidiraju društvo i društvene odnose oko sebe. Na taj način se društvo u kojem je taj dokumentarni film nastao menja i otvara za nova saznanja o prošlosti i sadašnjosti. „Nudeći nove perspektive, sadržaje i lične priče, oni penetriraju dominantne istine i nude pukotinu kroz koju možemo da sagledamo nove realnosti." (Popadić et.al 2017, 43). Autori dokumentarnih 
filmova stoga moraju biti svesni društvene odgovornosti koju nose njihovi filmovi i moći koju oni imaju.

\section{MEDIJSKA PISMENOST, KULTURA I OBRAZOVANJE}

Aspekti medijske pismenost, kao što je analiza audio-vizuelnih sadržaja, kroz koju se dalje razvijaju kritički odnosi, ali i jača društvena odgovornost spram medijskih tekstova (od štampanih do ekranskih) (Milovanović 2016b), omogućavaju da medijsku pismenost u savremenom kontekstu sagledamo kao „skup gledišta koje u korišćenju medija aktivno primenjujemo da bismo protumačili značenje poruka koje primamo" (Poter 2011, 47). Međutim, specifičnosti dokumentarnog filma podrazumevaju razvijanje medijske pismenosti koja odgovara njegovim odlikama (izbor tema i sagovornika, autorski ugao spram ideje i sadržaja, način na koji je snimljen i montiran, efekti tokom prikazivanja, itd.). Stoga je analiza sadržaja samo polazište za kritičko procenjivanje poruka koje su u njemu sadržane, na osnovu kojih se šire sposobnosti za komparaciju medijskih tekstova, stiču znanja za uočavanje njihovih sličnosti i razlika, sagledavanje kvaliteta jedne poruke i prepoznavanje njenih nedostataka kroz artikulaciju autentičnosti, pozitivno utičući na „zauzimanja moralnog stava o cilju i društvenim efektima neke poruke u konkretnom društvenom kontekstu“ (Popadić et.al 2017, 41). Ovako posmatrana namena i upotreba dokumentarnog filma u nastavi nastavnicima daje „čitavu lepezu prilika za privlačenje pažnje učenika i studenata, buđenje njihovih interesovanja za odabranu temu i inspiraciju za sopstvene aktivnosti i angažman." (Popadić et.al 2017, 42).

U tekstu Obrazovna i kulturna politika, dramske umetnosti u školama (2010) Vesna Đukić postavlja dva pitanja, od kojih je prvo u vezi sa proučavanjem odnosa između obrazovne i kulturne politike u Srbiji na različitim nivoima obrazovanja. Drugo pitanje u njenom istraživanju tiče se uloge audio-vizuelnih umetnosti u obrazovnom sistemu, kao i postojećih i mogućih oblika „zastupljenosti ove umetničke discipline u nastavnim programima škola u Srbiji“ (Đukić 2010, 195). U sistemu formalnog osnovnog i srednjeg obrazovanja u Srbiji postoji neravnomerna zastupljenost umetničkih disciplina „zbog koje su likovna i muzička kultura zastu- 
pljene u nastavnom programu kao nastavni predmeti, dok su dramske umetnosti zastupljene samo neformalnim i informalnim sistemom vannastavnih aktivnosti“ (Đukić 2010, 196). Svrha savremenog obrazovanja u Srbiji, navodi Đukićeva, definisana je u nastavnom planu za osmi razred osnovnog vaspitanja i obrazovanja kao „kvalitetno obrazovanje i vaspitanje, koje omogućava sticanje jezičke, matematičke, naučne, umetničke, kulturne, zdravstvene, ekološke i informatičke pismenosti, neophodne za život u savremenom i složenom društvu“" (Đukić 2010, 203). Pored navedenih različitih oblika pismenosti neophodnih za život, ovaj nastavni plan uključuje i „umetničku i kulturnu pismenost“ (ibid).

Postojeći školski kurikulumi u osnovnim i srednjim školama poznaju tri različita oblika učenja, i to: o umetnosti, pomoću umetnosti i za umetnost:

„U sistemu učenja o umetnosti, ona se proučava u okviru nastavnih predmeta kao što su jezik (srpski i maternji), muzička kultura, likovna kultura i drugi (domaćinstvo, informatika); u sistemu učenja pomoću umetnosti - ona se koristi kao metod učenja i način produbljivanja razumevanja različitih predmeta obuhvaćenih nastavnim programom; u učenju za umetnost koji je razvijen u osnovnim i srednjim umetničkim školama i fakultetima - učenici i studenti obučavaju se za umetničko stvaralaštvo." (Đukić 2010, 200).

Umetnička, kulturna, medijska i filmska pismenost dece i omladine značajan je faktor formiranja kulturnih potreba, navika i interesovanja pomoću kojih oni razvijaju svoju ličnost tako da „aktivno deluje, proizvodi, stvara nove materijalne i duhovne vrednosti, uživa u postojećim, komunicira" (Dragićević-Šešić/Stojković 2003, 16). S obzirom na to da ovi faktori zavise od obrazovanja, kao i od drugih kulturnih, socijalnih i materijalnih okolnosti, „potrebno je da postoji funkcionalna povezanost obrazovne i kulturne politike“ (Đukić 2010, 203).

\section{FILM U NASTAVI}

U publikaciji Film u nastavi, priručnik za studente - buduće nastavnike polazi se od ideje da film može da unapredi obrazovni program, 
„ali nije kurikulum“ (Russell 2009, 1). Navodi se da „film nije cilj, ni svrha nastave. Filmovima se otvaraju pitanja i problematizuju odgovori, (...) uvodi u raspoloženja i kontekste te otvara prostor za učenje" (Popadić et.al 2017, 43). Dokumentarni film u interaktivnoj nastavi bira se na osnovu umetničke i kulturne vrednosti, stavova koje interpretira, auktuelnosti i autentičnosti teme. Važno je prilagoditi njegov izbor kako interesovanju konkretne grupe i nastavnika, tako i stepenu njihove osetljivosti na sadržaj i vrednosni kontekst koji se iskazuje određenim filmom. Nastavni materijal priručnika čine hibridni model za rad sa dokumentarnim filmovima u nastavi, konkretne metode i aktivnosti na časovima sa filmskom projekcijom, kao i preporuka za diskusije posle zajedničkog gledanja. Sfera dokumentarnosti deo je „unikatnog instrumenta u obrazovanju koji može da otvori važne teme današnjeg sveta, da probudi našu osetljivost i izgradi kvalitetne međuljudske odnose" (Popadić et.al 2017, 10). Predmet Film u nastavi Master programa Centra za obrazovanje nastavnika na Filozofskom fakultetu naglašava da:

„film u interaktivnoj nastavi nije: ukras koji se dodaje tradicionalno dominantnom prenošenju znanja koji tradicionalnu nastavu čini savremenom; celovita nastavna aktivnost koja zamenjuje ostale aktivnosti; nastavno sredstvo koje ima instrumentalnu ulogu u usvajanju određenih znanja o svetu“ (Popadić et.al 2017, 49).

Zasnovani na autentičnom beleženju stvarnih događaja, često uz neposredne izjave svedoka, dokumentarni filmovi imaju potencijal da inspirišu i obrazuju, te snažno utiču na razvoj ličnosti i formiranje stavova spram predrasuda, stereotipa i događaja koji proizilaze iz društvenoistorijskog konteksta datog vremena. Dotičući svoje gledaoce na ličnom, emocionalnom, etičkom i socijalnom nivou, sadrže mnoge slojeve analize: teme i likove, predstavljanje i rešavanje aktuelnih pitanja i problema, stavove koji su zastupljeni i okolinu u kojoj se radnja odvija, itd. Podstičući rasuđivanje i formiranje vrednosne lestvice o savremenim temama, učenicima se „proširuje horizont njihovih znanja van granica uobičajene školske nastave. Takođe, razvija i sposobnost učenika da se suoče sa komplikovanošću savremenog sveta uz razvoj veština koje su im za to potrebne." (Popadić et.al 2017, 76). Podsticanjem novih trendova: 
„od obrazovanja se danas očekuje da doprinosi razvoju celovite ličnosti učenika, a ne samo sticanju naučnih znanja i razvoju kognitivnih sposobnosti, kao i da razvija kompetencije za delovanje u društvu. Zato je potrebno da se učenici osposobljavaju da oprezno sude i kritički preispituju informacije, zauzimaju odnos prema sebi i svetu, razumeju perspektive drugih, budu osetljivi za probleme $u$ društvu i da umeju da ih rešavaju, da se razvijaju njihovi kapaciteti za samoodređenje i produktivno učešće u kulturi. Ovakvo obrazovanje zahteva otvorenost škole za aktuelne društvene probleme i potrebe." (Popadić et.al 2017, 45).

Škola je institucija u kojoj bi trebalo da bude neophodno da se učenici obrazuju za analizu medijskih sadržaja, a reflektovanjem aktuelnih tema da se podstiče razvoj ličnosti učenika, njegovih stavova i vrednosti. Stoga je potrebno da nastavnici budu pripremljeni za edukaciju đaka za kritičko razumevanje medijskih poruka i ocenu njihovog uticaja u društvu. Angažovani dokumentarni filmovi prate: odnose ljudi i grupa; principe suživota i poštovanje drugih u društvu; načine (ne)verbalne komunikacije i delovanja u različitim životnim situacijama; prepoznavanje emocija, empatije, autorefleksije, moralnih i etičkih merila, itd. Podsticanjem razgovora nakon prikazivanja ovih filmova pojavljuju se teme koje se prostiru od otvorene i pozitivne komunikacije do agresije, laži i manipulacije. Zbog toga je adekvatnim metodama nastave neophodno usmeriti razgovor $u$ pravcu sledećih tema:

„razumevanje i poštovanje sociokulturne raznovrsnosti koja se neprestano širi; ravnopravnost jedinaca i grupa; socijalna kohezija; negativan uticaj diskriminacije, ksenofobija i ekstremizam; kršenje ljudskih prava. Dokumentarni film nam može pomoći da produbimo znanja iz nekih osovnih pojmova multikulturne terminologije: kultura, etnička pripadnost, identitet, diskriminacija, ksenofobija, rasizam, nacionalnost, netolerancija i sl.“ (Popadić et.al 2017, 73).

U savremenim teorijama učenje je predstavljeno kao razumevanje i razmena iskustva, zbog čega je važno obezbediti interakciju sa drugima u sigurnom okruženju i atmosferi međusobnog poštovanja u školi. Na ovako 


\section{ZAKLJUČAK}

Kompleksna tematika dokumentarnog žanra inspiriše, stimuliše i provocira dijalog, ali ne nudi gotov model za diskusiju u nastavi. Tek povezanom (inter)akcijom na času moguće je ostvariti slojevitu analizu, za koju je esencijalno interesovanje učenika (šta ih čudi, zbunjuje, o čemu se pitaju, itd.). Od presudne važnosti su aktuelnost teme i vrednosti koje film zastupa, njegov umetnički kvalitet, autentičnosti problema koje predstavlja, multiperspektivni potencijal povezivanja sa drugim fenomenima. Sve dosadašnje publikacije Slobodne zone Junior pružaju jedinstvenu mogućnost da se profesionalci u obrazovanju osposobe za korišćenje dokumentarnog filma kao nastavnog sredstva. Predstavljanjem metodike za ovu vrstu nastave, otvara se novo polje za učenje i istraživanje kulture, istorije, politike i društva u kojem su nastali dokumentarni filmovi koji su izabrani za nastavu.

\section{Literatura:}

Britton, Andrew (1992) „The Invisible Eye“, Sight and Sound, March 1992, pp. 26-29.

Dragićević Šešić, Milena i Dragojević, Sanjin (2005) Menadžment umetnosti u turbulentnim okolnostima, Beograd: Clio.

Đukić, Vesna (2010) „Obrazovna i kulturna politika: Dramske umetnosti u školama“, Zbornik Fakulteta dramskih umetnosti br.16, Beograd: Fakultet dramskih umetnosti, str. 195-209.

Film Kultura na lokaciji: http://www.filmkultura.org/sr/ pristupljeno decembra 2018.

Gone, Žak (1998) Obrazovanje i mediji, Beograd: Clio.

Ibrahim, Yasmin (2009) „Holocaust as the Visual Subject: The Problematic of Memory Making through Visual Culture." Nebula, Volume 6, Issue 4, pp.94-113.

Kerner, Aron (2011) Film and the Holocaust, New Perspectives on Dramas, Documentaries and Experimental Film. London: The Continuum International Publishing Group.

Lardoux, Xavier (2014) For a European Film Education Policy, na lokaciji: http://www. kulturnibazar.si/scripts/download.php?file=/data/upload/For_a_European_ Film_Education_Policy_A_Report_by_Xavier_Lardoux.pdf pristupljeno decembra 2018.

Makluan, Maršal (2012) Elektronski mediji i kraj kulture pismenosti, Loznica: Karpos.

Milovanović, Aleksandra (2016a) „Moć i društvena odgovornost dokumentarnog filma: RTV Beograd 1990-1995“, Zbornik radova: Interpretacije jugoslovenskih sukoba i njihove posledice: između suštinskog neslaganja i dijaloga, ur. Goran Tepšić, Radmila Nakarada, Nemanja Džuverović. Beograd: Fakultet političkih nauka i Forum 
Ziviler Friedensdienst, str. 265-278.

Milovanović, Aleksandra (2016b) „Medijska pismenost: funkcionalna (ne)povezanost ekranske kulture i školskih kurikuluma", Zbornik radova: Digitalna humanistika, Beograd: Filološki fakultet, str. 127-142.

Popadić, Dragan, Aksentijević, Zagorka, Ranđelović, Melita, Štrbić, Vesna i Vajzner, Aleksandar (2008) Slobodna zona u srednjim školama: filmovi u nastavi građanskog vaspitanja, Beograd: Fond B92.

Popadić, Dragan, Aksentijević, Zagorka, Ranđelović, Melita, Štrbić, Vesna i Vajzner, Aleksandar (2009) Slobodna zona u srednjim školama: filmovi u nastavi građanskog vaspitanja, Beograd: Fond B92.

Popadić, Dragan, Rajović, Vera, Radulović, Lidija i Stančić, Milan (2017) Film u nastavi, priručnik za studente - buduće nastavnike, Beograd: Fond B92.

Poter, Džejms (2011) Medijska pismenost, Beograd: Clio.

Ranđelović, Melita i Štrbić, Vesna (2011) Slobodna zona: priručnik za osnovne škole: filmovi u nastavi građanskog vaspitanja, Beograd: Fond B92.

Reid, Mark (2013) Screening Literacy, Film Education in Europe, London: BFI.

Russell, William B. (2009). Teaching Social Issues with Film. Charlotte, NC: Information Age Publishing.

Slobodna Zona Junior, na lokaciji: http://www.freezonebelgrade.org/slobodna-zona-junior pristupljeno decembra 2018.

Sobchack, Vivian 1999. "Toward a Phenomenology of Non-Fictional Experience." Collecting Visible Evidence, ed. Michael Renov and Jane Gaines. Minneapolis: University of Minnesota Press, pp. 241-254.

\section{Aleksandra Milovanović}

\section{DOCUMENTARY FILM IN THE EDUCATIONAL PROCESS: RE-POSITIONING THE GOALS}

\section{Summary}

The aim of this paper is to investigate the effects of the published handbooks of the Free Zone Junior (B92 Fund), which reposition a documentary film in the educational process of Serbia, primarily in the teaching of civic education in elementary and secondary schools, and then at University through the master program of the Centre for Teacher Education at the Faculty of Philosophy. The main focus will be on the publication Film in Teaching: a manual for students - future teachers (2017), which as the fundamental and recommended method of teaching states that by analysing the largest number of documentary films one can further explore their cultural, social, historical and political significance in the society in which they were created. It also states that the authors 
of documentary films tend to make them more approachable and present a world to the audience which they do not want or cannot see. Making a documentary film, the artist has the responsibility to ask questions, invite to a debate, explore, review, analyse, complement and revise the society and social relations around him. This results in the fact that the society in which the documentary film was created changes and opens up for new knowledge about the past and the present. Consequently training professionals in education to use documentary film as a teaching tool has the potential to inspire dialogue and open topics for debate.

Key words: documentary film, debate, teaching methodology, educational system, Serbia. 